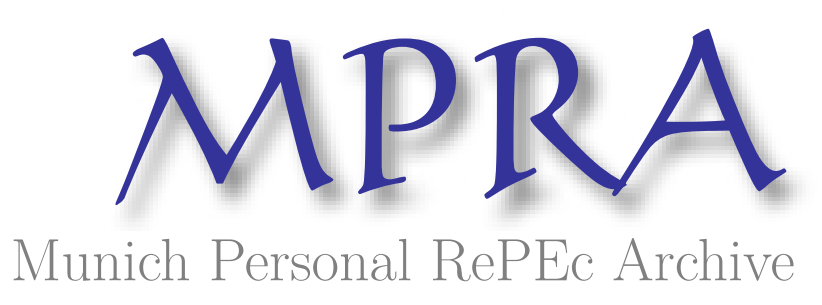

\title{
Ignorance is bliss: Should a pension reform be announced?
}

Fedotenkov, Igor

Bank of Lithuania

1 May 2016

Online at https://mpra.ub.uni-muenchen.de/71336/

MPRA Paper No. 71336, posted 16 May 2016 14:08 UTC 


\title{
Ignorance is bliss: Should a pension reform be announced?
}

\author{
Igor Fedotenkov ${ }^{1}$
}

Bank of Lithuania

\begin{abstract}
This paper studies whether a pension reform, namely a switch from a payas-you-go (PAYG) to a more-funded scheme should be announced. We show that such an announcement increases savings, leading to a decline in interest rates. Smaller returns to savings lead to higher losses for the first transitional generation, which suffers from the reform the most. On the other hand, higher savings by the first transitional generation lead to faster capital accumulation, which benefits younger generations. We argue that if a government cares about the agents with the most to lose, it may more beneficial not to announce such a reform.
\end{abstract}

JEL Classification: E13, E21, H55

Keywords: Pension reform, announcement, savings, interest rate

\footnotetext{
${ }^{1}$ Economics Department, Bank of Lithuania; The views expressed are those of the author and do not necessarily represent those of the Bank of Lithuania.

Contacts: i.fedotenkov@gmail.com, +37060326377
} 


\section{Introduction}

Many countries have recently reformed their pension schemes, or are planning to do so soon, one of the most popular changes being a switch from a pay-as-you-go (PAYG) to a more funded scheme. It is well known that in a dynamically efficient economy, such a reform reduces the welfare of the elderly living at the time of the reform and improves the welfare of the young (Breyer 1989). In order to mitigate the losses to the older generation, governments may wish to announce the reform as early as possible, in order to let transitional generations reallocate consumptions in time according to their intertemporal preferences. However, we show that the optimal policy could be the contrary. Indeed, lower expected pensions in the future increase savings, leading not only to less consumption when young, but also reducing interest rates, which affect consumptions in the future. As a result, agents' response to the announcement is harmful to themselves. However, younger generations are better off if the reform is announced in advance as they will enjoy a greater amount of capital.

The work most relevant to our paper is that of Bütler (1999). She showed that an anticipated decline in pension benefits substantially reduces consumption and negatively affects welfare prior to the reform's implementation. We extend this finding by comparing the agents' lifetime benefits and losses when a pension reform is announced versus unannounced.

Santoro (2006) studied the effects of the early announcement of a rise in pension age and minimal working period needed to qualify for public pensions in Italy. She found that many eligible workers chose to retire in the period between the announcement and the implementation of this reform. Our paper differs from Santoro in the type of pension reform considered (reduced public pensions rather than increased pension age).

Usually, a switch from a PAYG to a more-funded pension scheme is associated with a reduction in PAYG contributions. Mertens and Ravn (2012) found that pre-announced tax cuts reduce output, investments and hours worked, prior to their implementation, as agents reallocate their economic activities to the next period. Later, the reform stimulates the economy. Based on this finding, Cardi and Restout (2014) showed that, in an open economy, a switch from labour taxes to consumption taxes leads to a greater rise in GDP if the reform is unannounced. Our result is in line with these findings; however, in contrast, our results are determined by increased personal savings, which function as an externality since they reduce interest rates.

\section{The model}

\section{$2.1 \quad$ Firms}

The economy in the model is assumed to be closed. Capital and labour markets are competitive. Production function $\left(Y_{t}\right)$ has a standard Cobb-Douglass form, wages $\left(w_{t}\right)$ and interest rates $\left(r_{t+1}\right)$ being equal to the marginal returns to 
labour $\left(L_{t}\right)$ and capital $\left(K_{t}\right)$ :

$$
\begin{gathered}
Y_{t}=K_{t}^{\alpha} L_{t}^{1-\alpha}, \\
w_{t}=(1-\alpha) k_{t}^{\alpha}, \\
1+r_{t}=\alpha k_{t}^{\alpha-1} .
\end{gathered}
$$

Capital depreciates in one period and $k_{t}$ is a capital-labour ratio.

\subsection{Agents}

Agents live for two periods and maximise a lifetime logarithmic utility function:

$$
U_{t}=\log C_{t}^{y}+(1+\rho)^{-1} \log C_{t+1}^{o},
$$

where $C_{t}^{y}$ denotes consumption when young, $C_{t+1}^{o}$ - consumption when old; $\rho$ is a discount factor. Budget constraints are:

$$
\begin{array}{r}
C_{t}^{y}=w_{t}\left(1-\tau_{t}\right)-s_{t}, \\
C_{t+1}^{o}=s_{t}\left(1+r_{t+1}\right)+\tau_{t+1}^{e} w_{t+1}(1+n),
\end{array}
$$

where $s_{t}$ refers to savings, $n$ - population growth, $\tau_{t}$ is a contribution to a DC pension scheme, $\tau_{t+1}^{e}$ denotes expected contribution to the pension scheme in the next period. When the next period begins, the actual contribution is realised and $\tau_{t+1}^{e}$ is replaced by its actual realisation $\tau_{t+1}$. We assume that $\tau_{t+1}^{e}=\tau_{t}$ if the reform is unexpected, and $\tau_{t+1}^{e}=\tau_{t+1}, \tau_{t+1}<\tau_{t}$, when it was announced one period before its implementation.

Plugging budget constraints into the utility function and maximising it with respect to savings, we received

$$
s_{t}=\frac{w_{t}\left(1-\tau_{t}\right)}{2+\rho}-\frac{w_{t+1}(1+\rho)(1+n)}{(2+\rho)\left(1+r_{t+1}\right)} \tau_{t+1}^{e} .
$$

Capital amount at $t+1$ is determined by savings at time $t: k_{t+1}=s_{t} /(1+n)$. Using this equality and equations (2-3), savings can be expressed as

$$
s_{t}=\frac{\alpha(1-\alpha) k_{t}^{\alpha}\left(1-\tau_{t}\right)}{\tau_{t+1}^{e}(1-\alpha)(1+\rho)+\alpha(2+\rho)} .
$$

\section{Optimality}

In this section we consider the lifetime utility of the older generation alive at the time of pension reform. Insert (2-3) and (8) to expressions (5-6):

$$
\begin{array}{r}
C_{t}^{y}=\left(1-\tau_{t}\right)(1-\alpha) k_{t}^{\alpha}\left(1-\frac{\alpha}{\tau_{t+1}^{e}(1-\alpha)(1+\rho)+\alpha(2+\rho)}\right), \\
C_{t+1}^{o}=\left(\frac{\alpha(1-\alpha) k_{t}^{\alpha}\left(1-\tau_{t}\right)}{\tau_{t+1}^{e}(1-\alpha)(1+\rho)+\alpha(2+\rho)}\right)^{\alpha}(1+n)^{1-\alpha}\left[\alpha+\tau_{t+1}(1-\alpha)\right] .
\end{array}
$$


Figure 1: Equivalent variation

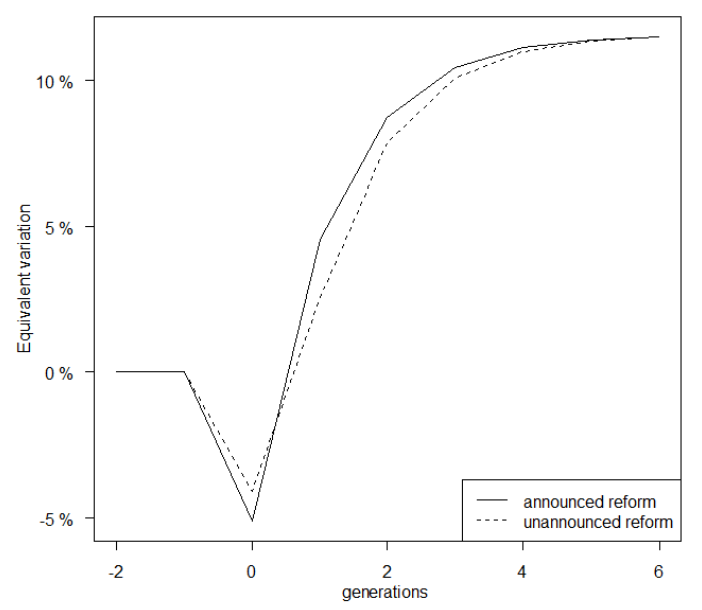

Plugging these expressions into the utility function, it is possible to maximise it with respect to $\tau_{t+1}^{e}$. Note that other variables at time $t$ are constant. ${ }^{2}$ The maximum is achieved when $\tau_{t+1}^{e}=1$. If $\tau_{t+1}^{e}<1$ the utility's derivative with respect to $\tau_{t+1}^{e}$ is positive, i.e. agents get a higher lifetime utility if they overestimate their pension benefits. Given this result, $\tau_{t+1}<\tau_{t}$ implies that elderly agents at the time of the reform get a higher utility if the reform was unannounced.

It should be stressed that the optimality condition is received only for the first transitional generation, which suffers the most from the pension reform. The maximisation problem for other generations would have to take capital accumulation into account.

\section{Transitional dynamics}

In this numerical example we present short-run welfare effects. Parameter values are usually used in the literature: $\alpha=0.4, \rho$ corresponds to a $1 \%$ annual discount rate, keeping in mind that one period lasts for 35 years, $n=0, \tau_{t}=0.2$ for $t \leq 0$ and $\tau_{t}=0.15$ if $t \geq 1$; therefore, tax reform takes place at $t=1$.

Figure 1 presents welfare effects for generations in terms of equivalent variation. It can be seen that if the reform is announced, a generation born at $t=0$ has higher welfare losses than if the pension reform were unannounced. But, if

\footnotetext{
${ }^{2}$ This an easy task, because omitting irrelevant constants, utility maximisation is equivalent to the maximisation of $\log X+\alpha(1+\rho)^{-1} \log (1-X)$, with respect to $X$, where $X=\alpha\left[\tau_{t+1}^{e}(1-\right.$ $\alpha)(1+\rho)+\alpha(2+\rho)]^{-1}$.
} 
the reform is expected, the gains of the transitional generations born at $t \geq 1$ are higher. Indeed, in this case, agents born at $t=0$ increase their savings, leading to a greater amount of capital at $t=1$; higher capital-labour ratio at $t=1$, in turn, leads to higher wages, and, consequently, increased savings in the generation born at $t=1$. However, generations born at $t \geq 1$ are better off independent of whether the reform is announced or not.

\section{Robustness}

As a robustness check, we made numerical simulations assuming a CES production function. Welfare effects with all the parameters we tried were very similar if the model was dynamically efficient and an internal equilibrium existed. However, for low elasticities of substitution there was no internal equilibrium.

Some differences may be noted if the logarithmic utility function is replaced by the CES form. For reasonable parameter values the conclusion remains the same; but if the elasticity of intertemporal substitution is very low ( $\leq 0.04$ with other parameter values unchanged from our numerical example), the result no longer holds. Indeed, if consumptions in different periods are almost perfect complements and the reform is unannounced, the first transitional generation's decline in consumption when old is not compensated by higher consumption when young (compared with the announced reform).

The finding of the paper also depends on specific model assumptions. The economy is assumed to be closed, but in the case of a small open economy, pension reform and its announcement do not change interest rates; as a result, the effect discussed in this paper no longer holds. However, if the economy is

open and (relatively) large, the results still hold, while losses and benefits of this reform spillover to the neighboring countries. This result can be seen in an earlier draft of this paper (Fedotenkov 2012, chapter 6).

Moreover, the effect presented in the paper depends on the assumption that there is no habit formation as in the Campbell-Cochrane model (Campbell and Cochrane 1999). It is very likely that the inclusion of habit formation in the model could significantly change the results. Another assumption, which may affect our results, is the absence of static inefficiencies. If pension reform reduces static inefficiencies, the government may issue debt to compensate losses of the older generation, and pay out this debt by taxing benefits of the younger and future generations (See Homburg (1990), for example). In our case, expectations of such a reform would affect the size of the debt that the government would issue.

\section{Conclusions}

In this paper, we showed that governments may have incentives not to announce a shift from a PAYG to a more-funded pension scheme, because agents, who expect such a reform, reduce their consumptions at the time of announcement. 
This increases savings and reduces the interest rate, which has a negative impact on agents' welfare. However, such an announcement increases the welfare of subsequent generations due to a higher amount of capital in the following periods. Clearly, such a result calls into question whether an unannounced pension reform is politically feasible. This would most likely depend on the individual country; however, governments may consider reducing the time be-

tween announcement and implementation in order to protect agents who suffer the most.

\section{Acknowledgments}

The paper was not funded by any organisation and it received no grants. I would like to thank Tadas Gedminas for his useful comments and Steve Guttenberg for his help with the English.

\section{References}

Breyer, F. (1989). On the intergenerational Pareto efficiency of pay-as-you-go financed pension systems. Journal of Institutional and Theoretical Economics 145, 643-658.

Bütler, M. (1999). Anticipation effects of looming public-pension reforms. Carnegie-Rochester Conference Series on Public Policy 50(1), 119-159.

Campbell, J. Y. and J. Cochrane (1999). Force of habit: A consumptionbased explanation of aggregate stock market behavior. Journal of Political Economy 107(2), 205-251.

Cardi, O. and R. Restout (2014). Unanticipated vs. anticipated tax reforms in a two-sector open economy. Open Economies Review 25(2), 373-406.

Fedotenkov, I. (2012). Pensions and ageing in a globalizing world. International spillover effects via trade and factor mobility. Ph. D. thesis, Tilburg University.

Homburg, S. (1990). The efficiency of unfunded pension schemes. Journal of Institutional and Theoretical Economics 146, 630-647.

Mertens, K. and M. O. Ravn (2012). Empirical evidence on the aggregate effects of anticipated and unanticipated US tax policy shocks. American Economic Journal: Economic Policy 4 (2), 145-181.

Santoro, M. I. M. (2006). Early announcement of a public pension reform in Italy. Rivista di Politica Economica 96(5), 179-216. 